\title{
Identification of a Pax6-Dependent Epidermal Growth Factor Family Signaling Source at the Lateral Edge of the Embryonic Cerebral Cortex
}

\author{
Stavroula Assimacopoulos, Elizabeth A. Grove, and Clifton W. Ragsdale \\ Department of Neurobiology, Pharmacology, and Physiology, The University of Chicago, Chicago, Illinois 60637
}

\begin{abstract}
In an emerging model, area patterning of the mammalian cerebral cortex is regulated in part by embryonic signaling centers. Two have been identified: an anterior telencephalic source of fibroblast growth factors and the cortical hem, a medial structure expressing winglessint (WNT) and bone morphogenetic proteins. We describe a third signaling source, positioned as a mirror image of the cortical hem, along the lateral margin of the cortical primordium. The cortical antihem is identified by gene expression for three epidermal growth factor (EGF) family members, Tgf $\alpha$, Neuregulin 1, and Neuregulin 3, as well as two other signaling molecules, Fgf7 and the secreted WNT antagonist Sfrp2. We find that the antihem is lost in mice homozygous for the Small eye (Pax6) mutation and suggest the loss of EGF signaling at least partially explains defects in cortical patterning and cell migration in Small eye mice.
\end{abstract}

Key words: cortical patterning; Tgf $\alpha$; Neuregulin; Sfrp2; Fgf7; Small eye; Pax6; Emx2

\section{Introduction}

Recent studies indicate that regional specification and growth control of the cerebral cortex is initiated by signaling centers operating on an originally homogeneous embryonic field (Fukuchi-Shimogori and Grove, 2001; Ragsdale and Grove, 2001; Hebert et al., 2002; Garel et al., 2003). Anteroposterior position is conferred by an anterior fibroblast growth factor (FGF) source (Fukuchi-Shimogori and Grove, 2001), and mediolateral pattern is regulated by the cortical hem, a medial signaling center enriched in bone morphogenetic proteins (BMPs) and wingless-int (WNT) proteins (Grove et al., 1998; Lee et al., 2000; Ragsdale and Grove, 2001; Hebert et al., 2002). Given the size and complexity of the final cortical area map, however, additional cortical signaling sources are almost certain to exist.

We hypothesized that the lateral edge of the cortical primordium, where the dorsal and ventral telencephalon meet, might be the site of an additional signaling center. The lateral cortical margin is readily identified by gene expression for a WNT antagonist, the secreted frizzled-related protein Sfrp2 (see Fig. 1) (Ragsdale et al., 2000; Kim et al., 2001). Sfrp2 expression is detected in this territory as early as embryonic day 10.5 (E10.5) (data not shown) and, by E12.5, describes a curve that laterally mirrors the medial cortical hem, itself identifiable by the expression of multiple Wnt

Received Dec. 12, 2002; revised May 7, 2003; accepted May 16, 2003.

This work was supported by a research grant from the National Alliance for Research on Schizophrenia and Depression (E.A.G.) and by grants from the National Institutes of Health (E.A.G., C.W.R.). We thank D. Anderson, E. Boncinelli, S. Dey, P. Godowski (Genentech, South San Francisco, CA), D. Lee, J. Nathans, R. Nusse, J. Pascall, J. Rubenstein, and D. Taylor (Bristol-Myers Squibb, Princeton, NJ) for gifts of plasmid DNA, P. Gruss and D. O'Leary for the Emx2 mutant mice, R. Maas for the Sey mice, and Anna Mae Greenlee and Eun Paik for technical assistance. We thank Dan Geschwind and Angeliki Louvi for valuable discussions.

Correspondence should be addressed to Clifton W. Ragsdale, Department of Neurobiology, Pharmacology, and Physiology, The University of Chicago, 947 East 58th Street, Chicago, IL 60637. E-mail: c-ragsdale@uchicago.edu. Copyright $\odot 2003$ Society for Neuroscience $\quad$ 0270-6474/03/236399-05\$15.00/0 genes (see Fig. 1A). Together, these territories mark the lateral and medial limits of the cortical ventricular zone (VZ) (see Fig. $1 C, D)$. Two-color in situ hybridization experiments suggest a pincer arrangement between the hem and the Sfrp2-rich antihem; the two territories are well separated in rostral telencephalon but approach one another to meet in the caudal telencephalon (see Fig. 1C).

If the antihem is an important embryonic signaling center, it is expected from studies of other cortical signaling centers to express multiple members of at least one secreted signaling molecule family. Two lines of research prompted a survey of epidermal growth factor (EGF) family members. First, a classic series of in vitro experiments implicates EGF family members in the development of cerebral cortical areas linked to the limbic system (Ferri and Levitt, 1993; Levitt et al., 1997). The limbic systemassociated membrane protein LAMP is expressed in limbic cortical areas (Levitt et al., 1997) and is upregulated in cells from non-limbic cortical domains in response to EGF family ligands (Ferri and Levitt, 1995). Second, EGF receptor-mediated signaling controls dorsoventral neuronal specification in the development of the Drosophila ventral nerve cord (Skeath, 1998; von Ohlen and Doe, 2000). Two EGF ligands are involved in this dorsoventral signaling: Spitz, a Tgf $\alpha$-like molecule, and Vein, which is similar in structure to the Neuregulin proteins, a subfamily of vertebrate EGF ligands (Golembo et al., 1999).

\section{Materials and Methods}

Gene expression patterns were studied in CD-1 mice, Small eye (Sey, or $\left.\mathrm{Pax}^{\mathrm{Sey}-\mathrm{Neu}}\right)$ mice maintained on a C3H/He background, and Emx2targeted mice maintained on a C57BL/6 background. The day of plug discovery was designated E0.5. In situ hybridization of E9.5-E18.5 forebrains and genotyping of the Sey and Emx2 mice were performed as described previously (Pellegrini et al., 1996; Xu et al., 1997; Grove et al., 1998). Antihem marker genes were studied with mouse cDNAs for Areg/ 


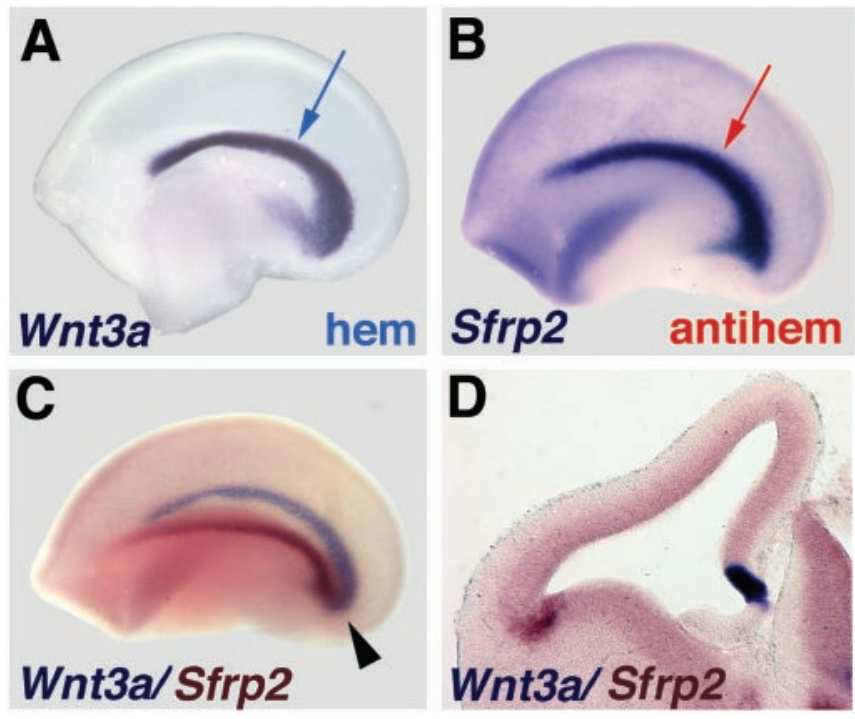

Figure 1. Location of the cortical hem and antihem. $A-C, E 12.5$ cerebral hemispheres, processed with one- or two-color in situ hybridization and viewed from the medial $(A)$ or lateral $(B$, C) faces. Anterior to the left. $D$, Coronal section through E12.5 cerebral hemisphere processed with two-color in situ hybridization. $A, B$, The "swoosh" of the medial cortical hem ( $A$, blue arrow) is mirrored by the lateral antihem ( $B$, red arrow). Together, they form a pincer arrangement around the cortical primordium ( $(C$ ). The cortical hem is marked by strong Wnt3a expression (purple in $A, C, D$ ), and the antihem is identified by expression of Sfrp2 (purple in $B$; reddishbrown in $C, D)$. Arrowhead $(C)$ indicates meeting of the hem and antihem in the caudal cerebral hemisphere.

Amphiregulin (Das et al., 1995), Egf (Pascall and Brown, 1988), Hegfll Heparin-binding EGF-like growth factor/Diphtheria toxin receptor (IMAGE Consortium, GenBank accession number W80035), Fgf7l Keratinocyte growth factor (IMAGE Consortium, GenBank accession number BF159111), Nrg1 (IMAGE Consortium, GenBank accession number AI197081), Nrg2 (IMAGE Consortium, GenBank accession number AW476657), Nrg3 (Zhang et al., 1997), Nrg4 (IMAGE Consortium, GenBank accession number AA238077), Sfrp2 (Rattner et al., 1997), Tgfa/Tgf $\alpha$ (Vaughan et al., 1992; Kornblum et al., 1997), Tmeff1/ Transmembrane protein with EGF-like and two follistatin-like domains 1 (IMAGE Consortium, GenBank accession number BF147745) and Tmeff2/Tomoregulin (IMAGE Consortium, GenBank accession number AI098476), and a rat cDNA for Ereg/Epiregulin (Taylor et al., 1999).

\section{Results}

We examined mRNA expression of 11 EGF family members: Egf itself, Tgf $\alpha$, Neuregulins 1-4, Amphiregulin, Epiregulin, Heparin-binding EGF-like growth factor, Tmeff1, and Tmeff2. Our screen disclosed that the lateral margin of the cortical primordium is enriched in expression of three Spitz and Vein homologs, Tgf $\alpha$, Neuregulin1 (Nrg1), and Nrg3. At E12.5, Tgf $\alpha$ expression marks the antihem, which appears as a curve of strong $T g f \alpha$ expression when viewed from the lateral face of the cortical primordium (Figs. 1,2A). Coronal sections show that $\operatorname{Tg} f \alpha$ expression is in the VZ of proliferating cells (Fig. 3). Nrg1 and Nrg3 show overlapping high expression in the same curving band (Fig. $2 B, C)$. All three genes display some graded expression in the cortical VZ, which is most pronounced in $\mathrm{Nrg} 3$ preparations. For both $\mathrm{Nrg}$ genes, expression in the cortical primordium increased as development proceeded (last age examined, E18.5). For all three genes, however, the cortical antihem is the peak of expression in the cortical primordium.

Other EGF ligands, including Egf itself, were at least weakly detected in the embryonic telencephalon (Figs. $2 \mathrm{E}, 3 \mathrm{~K}, \mathrm{~L}$ ) (Kornblum et al., 1997) but not concentrated in the antihem. At E10.5,
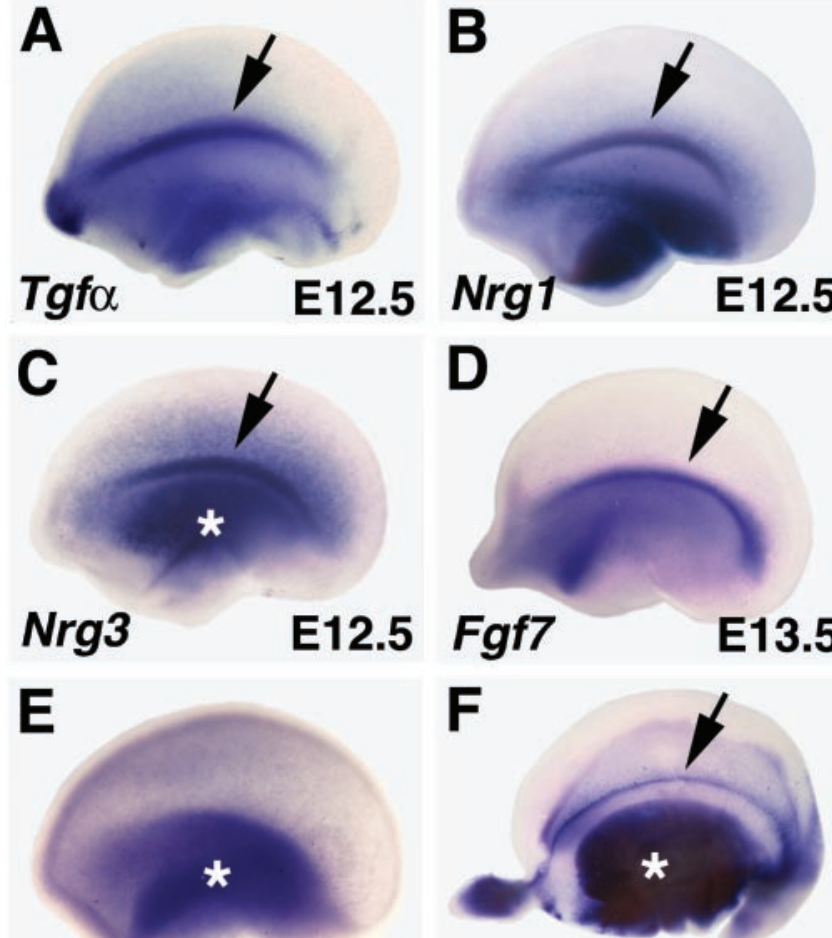

Egf E12.5 Tgfo

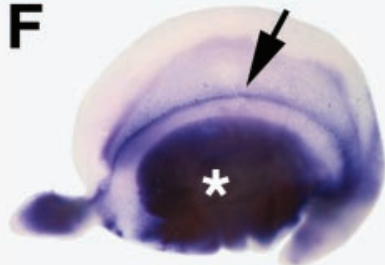

Figure 2. EGF family members are expressed in the cortical antihem. $A-E$, Embryonic cerebral hemispheres viewed from the lateral face; anterior to the left $(A-C, E, E 12.5 ; D, E 13.5) . F$, E18.5 hemisphere viewed from the inside looking laterally. A-C, Peaks of expression of $\operatorname{Tg} f \alpha$, $\mathrm{Nrg} 1$, and $\mathrm{Nrg} 3$ mark the curving longitudinal lateral band of the antihem (arrows in A-C). Tgf $\alpha$ expression is maintained for several days in this position (arrow, F). D, Fgf7 is also expressed in the antihem at E13.5.E, The founding member of the EGF family, Egfitself, is expressed in the ventral telencephalon and in the cortical primordium without a peak of expression at the antihem. Asterisks mark expression in ventral telencephalon $(C, E, F)$.

E12.5, and E14.5, Amphiregulin, Egf, Epiregulin, Hegf1, Nrg2, Nrg4, Tmeff1, and Tmeff2 are expressed in the ventral telencephalon, usually increasing in intensity with age. Most EGF family members are expressed in the dorsal telencephalon from E12.5 onward, with the exception of Nrg2, which is detectable at E10.5. No striking patterns of expression were detected except for Epiregulin and Tmeff1, which display expression gradients in far lateral and medial embryonic cortex.

In a screen of $F g f$ gene expression in and near the cortical primordium, we found that Fgf7 gene expression marks the antihem by E13.5 (Fig. 2 D). Transient embryonic expression of Fgf7 was noted previously in a lateral embryonic cortical region (Mason et al., 1994). Thus, together with Sfrp2, five secreted signaling molecules are expressed along the lateral edge of the cortical primordium.

The cortical hem is part of the true cortical primordium as characterized by progenitor cell behavior and gene expression (Grove et al., 1998). Tgf $\alpha$ expression at the antihem also lies within cortical primordium, defined by expression of Neurogenin2 (Ngn2) (Fig. 3A, B; two-color in situ data not shown). Sfrp2 expression is within the Tgf $\alpha$ domain and marks the extreme margin of the cortical primordium (Fig. 3G; Ngn2/Sfrp2 twocolor in situ data not shown). Fgf7 expression, which is strongest in the posterior antihem, overlaps that of $S f r p 2$ (Fig. $3 J$ ). In contrast, expression of $\mathrm{Nrg} 1$ and $\mathrm{Nrg} 3$ is not restricted to the cortical VZ but stretches into the VZ of the basal forebrain (Fig. 3C, H,I). 


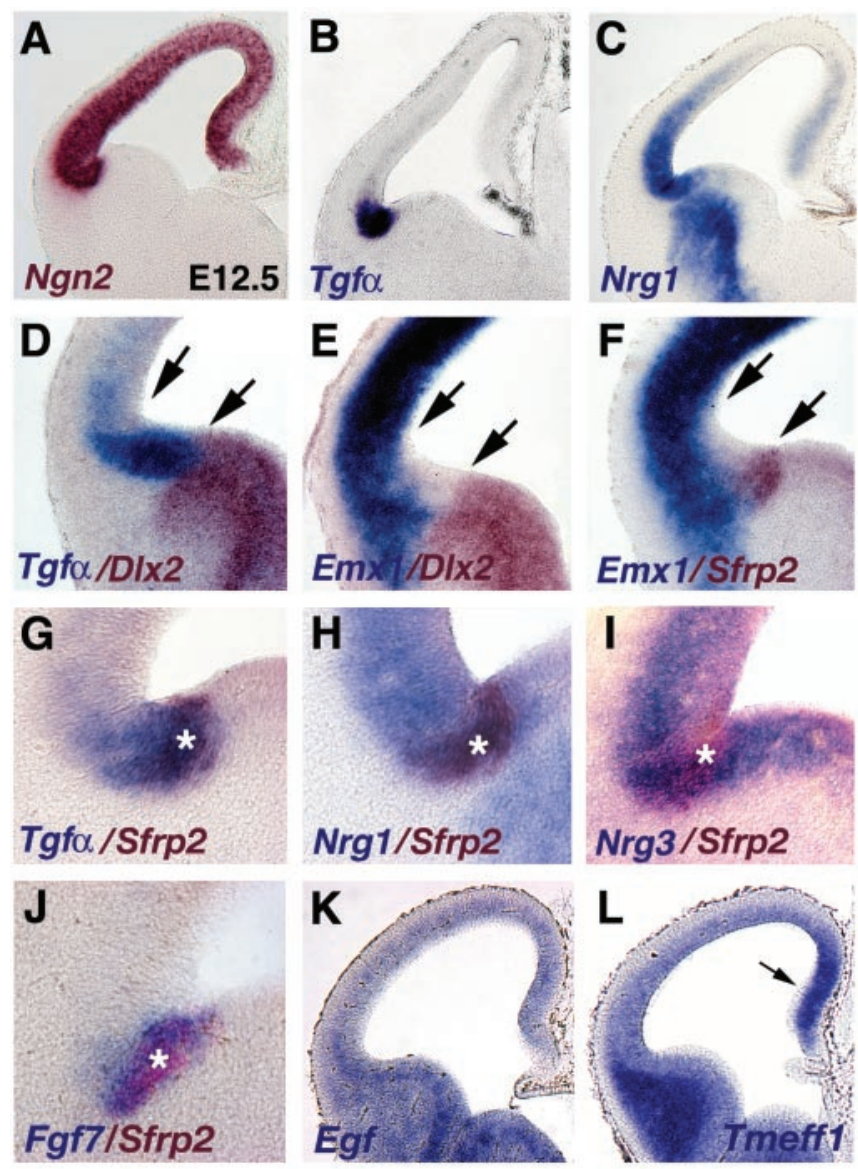

Figure 3. Location of the antihem relative to the transition between dorsal and ventral telencephalon. $A-L$, Coronal sections through E12.5 and E13.5 $(J)$ cerebral hemispheres processed for one- or two-color in situ hybridization. A, Ngn2 expression marks the boundaries of cortical neuroepithelium. $B$, The Tgf $\alpha$-expressing domain lies within the cortical primordium (compare A, B). C, Nrg1 expression peaks in the Tgf $\alpha$-rich domain but extends as a decreasing gradient into dorsolateral cortical neuroepithelium, with an additional zone of expression in the medial cortical primordium. $D-F$, At E12.5, a wedge-shaped territory lacks expression of Emx1 or Dlx2 (between arrows). This territory is filled by Tgf $\alpha$ expression (D), with Sfrp2 and Fgf7 expression nested in the $T g f \alpha$ domain $(F, G, J)$. Tgf $\alpha, F g f 7$, and Sfrp2 expression remain within cortical neuroepithelium at this site $(D, F, J)$, but $\mathrm{Nrg} 1$ and $\mathrm{Nrg} 3$ extend into the VZ of the basal telencephalon $(H, I)$. Asterisks $(G-J)$ mark the Sfrp2-expressing zone, the most lateral margin of the cortical neuroepithelium. $K, L$, At E12.5, Egf ( $K$ ) and Tmeff1 ( $L$ ), like other EGF family members, do not show gene expression peaks in the cortical antihem. Arrow $(L)$ notes increased Tmeff1 expression in medial embryonic cortex, as seen in Nrg1-labeled sections ( $($ ).

The transcription factor genes Emx1 and Dlx2 are differentially expressed in dorsal and ventral telencephalon. At E12.5, the boundaries of expression of Emx 1 and $D l \times 2$ leave an intermediate wedge clear of expression of either gene in the VZ of the lateral margin of the cortical primordium (Fig. 3E) (Fernandez et al., 1998). Two-color in situ hybridization shows that this wedgeshaped zone is antihem territory: it is filled by dense expression of $T g f \alpha$, and Sfrp 2 expression marks its ventral limit (Fig. 3D-G). Although the cells that compose the antihem do not express Emx1 at E12.5, they appear to do so at a later stage of development (Fernandez et al., 1998). Genetic fate mapping of Emx1expressing cells suggests that cells in this region give rise to portions of the amygdala and lateral cortex (Gorski et al., 2002).

The antihem shows both similarities and differences with other cortical signaling sources. For example, expression of EGF family genes are not detectable in the antihem at E10.5, an age at which Fgf, Wnt, and Bmp expression is prominent at other corti- cal signaling sources. Nrg1 and Tgf $\alpha$ are only barely detectable in the lateral cortical primordium at E11.5. Moreover, EGF gene expression does not overlap as neatly as the expression of multiple Wnt genes in the cortical hem or even of Fgf genes at the anterior pole. Particularly for the Nrg genes, mRNA expression extends as a gradient from the antihem into the more dorsolateral cortical VZ. Nonetheless, the antihem is similar to other signaling sources in representing a peak of expression of several members of a single signaling molecule family.

The Small eye (Sey) homozygote mutant mouse lacks function of the transcription factor Pax6 and displays impaired cortical neurogenesis, cell migration, and patterning (Chapouton et al., 1999; Bishop et al., 2000; Stoykova et al., 2000), as well as localized defects in the antihem region, losing Sfrp2 expression (Wawersik et al., 1999; Ragsdale et al., 2000; Kim et al., 2001). Tgf $\alpha$ and Nrg1 expression is also lost in the antihem (Fig. $4 A, B, E-H$ ), suggesting a complete absence of this signaling center in the homozygote mutant. Because of a possible general developmental delay in the mutant, these mice and littermate controls were analyzed for gene expression from E12.5 to E16.5 for Sfrp2 ( $n=9$ homozygotes; $n=18$ controls), $\operatorname{Nrg1}$ ( $n=6$ homozygotes; $n=10$ controls), and Tgf $\alpha$ ( $n=12$ homozygotes; $n=21$ controls). At E14.5, $T g f \alpha$ expression marks the antihem in controls but is eliminated in homozygote mutants (Fig. 4A,B,E,F). Expression of $\mathrm{Nrg} 1$ in the lateral cortical VZ is almost undetectable in the homozygote Sey mouse, with the result that the gradient of expression is reversed, medial to lateral, with highest Nrgl expression in the hippocampal primordium (Fig. $4 H$, asterisk). Dense expression of $\mathrm{Nrg} 1$ appears at the antihem region in littermate mice at E14.5 (Fig. $4 E$ ), with a stronger gradient in the rest of the cortical primordium than in CD-1 mice (compare with Fig. $2 B$ ).

Mice lacking the transcription factor Emx2 also show widespread defects in neurogenesis and patterning (Bishop et al., 2000; Mallamaci et al., 2000) with concomitant defects in signaling sources (Muzio et al., 2002). WNT signaling in the cortical hem region is affected, as is anteroposterior gene expression of the FGF receptor Fgfr3 (Muzio et al., 2002), suggesting that signaling along both mediolateral and anteroposterior axes is abnormal. We found that the antihem, marked by $T g f \alpha$ expression, is retained in the Emx2 homozygote mutant but appears dorsally displaced (Fig. 4C,D; data not shown).

\section{Discussion}

Several roles can be hypothesized for the cortical antihem. A likely possibility is that the antihem serves as a barrier between the dorsal and ventral telencephalon, in both pattern formation and cell migration. Localized Sfrp2 may limit the spread of WNT signaling between dorsal and ventral telencephalon (Ragsdale et al., 2000; Kim et al., 2001). More broadly, both at the antihem and within the cortical primordium, EGFs may antagonize BMP and WNT signaling. Genetic studies of Drosophila development show that EGF receptor-mediated signaling attenuates both Decapentaplegic (BMP) and Wingless (WNT) signals (O'Keefe et al., 1997; Szuts et al., 1997; Kubota et al., 2000). Thus, the lateral EGF source may assist in maintaining a distinction between the dorsal and ventral telencephalon and in regional patterning of the cerebral cortex. The latter role is supported by the ability of $T g f \alpha$ to convert nonlimbic to limbic cortex in vitro (Ferri and Levitt, 1995).

EGFs may also regulate cortical cell migration. In rodents, a large proportion of cortical interneurons derived from the ventral telencephalon migrate past the region of the antihem to populate the cortical primordium (Anderson et al., 2001). During fly 

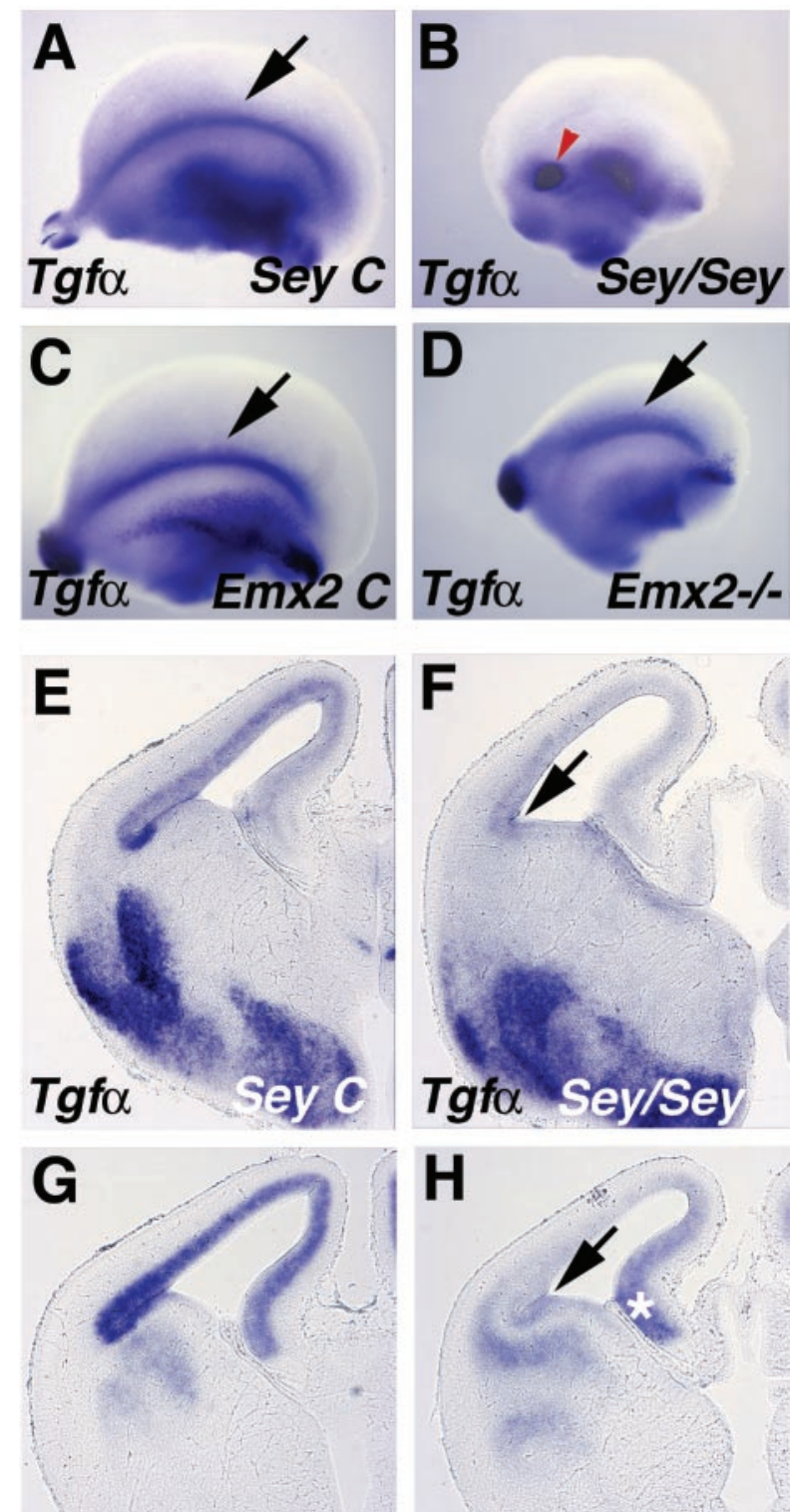

\section{Nrg1 SeyC Nrg1 Sey/Sey}

Figure 4. The antihem is lost in the Small eye mouse. $A-D$, Cerebral hemispheres viewed from the lateral face; anterior to the left. $E-H$, Coronal sections through E14.5 cerebral hemispheres. $A, B, E, F$, The antihem marked by Tgf $\alpha$ expression is missing in an E14.5 mouse homozygous for the Small eye mutation ( $B$, arrow in $F$ ) but is present in a littermate control (arrow in $A, E$ ). The spot of $\operatorname{Tgf} \alpha$ labeling in Sey homozygote mice (red arrowhead in $B$ ) is likely the olfactory bulb remnant (Jimenez et al., 2000). C, D, A Tgf $\alpha$-expressing antihem is present in an E13.5 Emx2 homozygote mutant mouse ( $D$, arrow) and littermate control $(C$, arrow) but appears dorsally displaced in the mutant $(D) . G, H, N r g 1$ expression is missing from the antihem region (arrow in $H$ ) and dorsolateral cortical neuroepithelium in an Sey/Sey mouse at E14.5, but expression in the hippocampal primordium remains (asterisk).

oogenesis, the Tgf $\alpha$-like ligand Gurken guides dorsal migration of border cells (Duchek and Rorth, 2001). Both overexpression of EGF family ligands and misexpression of a constitutively activated form of the EGF receptor inhibit border cell migration (Duchek and Rorth, 2001). Therefore, by analogy with fly developmental mechanisms, the antihem region in mouse, rich in EGF family members, could promote migration of the correct ventral telencephalic cells or inhibit the migration of incorrect cells. In retroviral studies of rodent telencephalic development, Caric et al. (2001) have found that increasing the EGF receptor levels in $\mathrm{VZ}$ cells promotes their radial migration away from the VZ. Thus, neurons born in the antihem region, which are thought to migrate toward ventrolateral cortical areas (Bayer et al., 1991), could be guided in part by the EGF ligands of the antihem.

Each of the above hypotheses receives support from analysis of the Sey/Sey mutant mouse, which lacks functional Pax6 and also appears to lack an antihem. First, patterning defects in the presumptive area map are seen in Sey/Sey cerebral cortex just before birth, with shrinkage of lateral and rostral cortical domains (Bishop et al., 2000). Second, gene expression patterns normally confined to the ventral or dorsal telencephalon transgress their usual boundaries in the Sey/Sey mutant; thus, the dorsoventral identity of the region around the antihem becomes ambiguous (Stoykova et al., 2000; Toresson et al., 2000; Yun et al., 2001). Third, ventral to dorsal cell migration is enhanced in the mutant, suggesting that incorrect cells are crossing the ventrodorsal telencephalic boundary and that Pax6 is essential to allow the correct cells to immigrate (Chapouton et al., 1999). We propose that Pax6 regulates development of the antihem and associated EGF ligand gradients and that the patterning and migration defects in the Sey/Sey mutant are at least in part mediated by the loss of the antihem. Finally, mice that lack Emx 2 show a subtler, but consistent, abnormality in this region. The antihem is present but shifted dorsally (this report), and LAMP expression, marking limbic cortex, is dorsally displaced in parallel (Mallamaci et al., 2000).

The antihem differs from other signaling centers by expressing signaling molecules later than other centers and in a more graded manner. However, these features may be significant to its potential cortical patterning function. As the cortical primordium grows larger, it becomes more difficult to explain how patterning could occur according to the classic model of a morphogen diffusing over an embryonic field with a width of $0.5 \mathrm{~mm}$ or less (Wolpert, 1969; Gurdon et al., 1994). Yet, cortical pattern remains labile relatively late in corticogenesis, when the embryonic cortex is larger than a typical embryonic field (Ragsdale and Grove, 2001). One way to prolong cortical patterning would be to introduce secondary signaling sources that generate a gradient of signaling protein directly. Thus, a gradient of EGF mRNA expression with a peak at the antihem may directly set up a patterning gradient of EGF proteins in the older and larger cortical primordium without a need for long-distance protein diffusion.

\section{References}

Anderson SA, Marin O, Horn C, Jennings K, Rubenstein JL (2001) Distinct cortical migrations from the medial and lateral ganglionic eminences. Development 128:353-363.

Bayer SA, Altman J, Russo RJ, Dai XF, Simmons JA (1991) Cell migration in the rat embryonic neocortex. J Comp Neurol 307:499-516.

Bishop KM, Goudreau G, O'Leary DD (2000) Regulation of area identity in the mammalian neocortex by Emx2 and Pax6. Science 288:344-349.

Caric D, Raphael H, Viti J, Feathers A, Wancio D, Lillien L (2001) EGFRs mediate chemotactic migration in the developing telencephalon. Development 128:4203-4216.

Chapouton P, Gartner A, Gotz M (1999) The role of Pax6 in restricting cell migration between developing cortex and basal ganglia. Development 126:5569-5579.

Das SK, Chakraborty I, Paria BC, Wang XN, Plowman G, Dey SK (1995) Amphiregulin is an implantation-specific and progesterone-regulated gene in the mouse uterus. Mol Endocrinol 9:691-705.

Duchek P, Rorth P (2001) Guidance of cell migration by EGF receptor signaling during Drosophila oogenesis. Science 291:131-133.

Fernandez AS, Pieau C, Reperant J, Boncinelli E, Wassef M (1998) Expression of the Emx-1 and Dlx-1 homeobox genes define three molecularly distinct domains in the telencephalon of mouse, chick, turtle and frog 
embryos: implications for the evolution of telencephalic subdivisions in amniotes. Development 125:2099-2111.

Ferri RT, Levitt P (1993) Cerebral cortical progenitors are fated to produce region-specific neuronal populations. Cereb Cortex 3:187-198.

Ferri RT, Levitt P (1995) Regulation of regional differences in the differentiation of cerebral cortical neurons by EGF family-matrix interactions. Development 121:1151-1160.

Fukuchi-Shimogori T, Grove EA (2001) Neocortex patterning by the secreted signaling molecule FGF8. Science 294:1071-1074.

Garel S, Huffman KJ, Rubenstein JL (2003) Molecular regionalization of the neocortex is disrupted in Fgf8 hypomorphic mutants. Development 130:1903-1914

Golembo M, Yarnitzky T, Volk T, Shilo BZ (1999) Vein expression is induced by the EGF receptor pathway to provide a positive feedback loop in patterning the Drosophila embryonic ventral ectoderm. Genes Dev 13:158-162.

Gorski JA, Talley T, Qiu M, Puelles L, Rubenstein JL, Jones KR (2002) Cortical excitatory neurons and glia, but not GABAergic neurons, are produced in the Emx1-expressing lineage. J Neurosci 22:6309-6314.

Grove EA, Tole S, Limon J, Yip L, Ragsdale CW (1998) The hem of the embryonic cerebral cortex is defined by the expression of multiple Wnt genes and is compromised in Gli3-deficient mice. Development 125:2315-2325.

Gurdon JB, Harger P, Mitchell A, Lemaire P (1994) Activin signalling and response to a morphogen gradient. Nature 371:487-492.

Hebert JM, Mishina Y, McConnell SK (2002) BMP signaling is required locally to pattern the dorsal telencephalic midline. Neuron 35:1029-1041.

Jimenez D, Garcia C, de Castro F, Chedotal A, Sotelo C, de Carlos JA, Valverde F, Lopez-Mascaraque L (2000) Evidence for intrinsic development of olfactory structures in Pax-6 mutant mice. J Comp Neurol 428:511-526.

Kim AS, Anderson SA, Rubenstein JL, Lowenstein DH, Pleasure SJ (2001) Pax-6 regulates expression of SFRP-2 and $W n t-7 b$ in the developing CNS. J Neurosci 21:RC132(1-5).

Kornblum HI, Hussain RJ, Bronstein JM, Gall CM, Lee DC, Seroogy KB (1997) Prenatal ontogeny of the epidermal growth factor receptor and its ligand, transforming growth factor alpha, in the rat brain. J Comp Neurol 380:243-261.

Kubota K, Goto S, Eto K, Hayashi S (2000) EGF receptor attenuates Dpp signaling and helps to distinguish the wing and leg cell fates in Drosophila. Development 127:3769-3776.

Lee SM, Tole S, Grove E, McMahon AP (2000) A local Wnt-3a signal is required for development of the mammalian hippocampus. Development 127:457-467.

Levitt P, Barbe MF, Eagleson KL (1997) Patterning and specification of the cerebral cortex. In: Annual Reviews of Neuroscience (Cowan WM, ed), pp 1-24. Palo Alto, CA: Annual Reviews.

Mallamaci A, Muzio L, Chan CH, Parnavelas J, Boncinelli E (2000) Area identity shifts in the early cerebral cortex of Emx2-/ - mutant mice. Nat Neurosci 3:679-686.

Mason IJ, Fuller-Pace F, Smith R, Dickson C (1994) FGF-7 (keratinocyte growth factor) expression during mouse development suggests roles in myogenesis, forebrain regionalisation and epithelial-mesenchymal interactions. Mech Dev 45:15-30.

Muzio L, DiBenedetto B, Stoykova A, Boncinelli E, Gruss P, Mallamaci A (2002) Emx2 and Pax6 control regionalization of the pre-neuronogenic cortical primordium. Cereb Cortex 12:129-139.
O’Keefe L, Dougan ST, Gabay L, Raz E, Shilo BZ, DiNardo S (1997) Spitz and Wingless, emanating from distinct borders, cooperate to establish cell fate across the Engrailed domain in the Drosophila epidermis. Development 124:4837-4845.

Pascall JC, Brown KD (1988) Structural analysis of the $5^{\prime}$-flanking sequence of the mouse epidermal growth factor gene. J Mol Endocrinol 1:5-11.

Pellegrini M, Mansouri A, Simeone A, Boncinelli E, Gruss P (1996) Dentate gyrus formation requires Emx2. Development 122:3893-3898.

Ragsdale CW, Grove EA (2001) Patterning the mammalian cerebral cortex. Curr Opin Neurobiol 11:50-58.

Ragsdale CW, Assimacopoulos S, Fukuchi-Shimogori T, Grove EA (2000) Early patterning of the cerebral cortex may be shaped by gradients of receptors and binding proteins of the FGF, BMP and WNT signaling pathways. Soc Neurosci Abstr 26:116.1.

Rattner A, Hsieh JC, Smallwood PM, Gilbert DJ, Copeland NG, Jenkins NA, Nathans J (1997) A family of secreted proteins contains homology to the cysteine-rich ligand-binding domain of frizzled receptors. Proc Natl Acad Sci USA 94:2859-2863.

Skeath JB (1998) The Drosophila EGF receptor controls the formation and specification of neuroblasts along the dorsal-ventral axis of the Drosophila embryo. Development 125:3301-3312.

Stoykova A, Treichel D, Hallonet M, Gruss P (2000) Pax6 modulates the dorsoventral patterning of the mammalian telencephalon. J Neurosci 20:8042-8050.

Szuts D, Freeman M, Bienz M (1997) Antagonism between EGFR and Wingless signalling in the larval cuticle of Drosophila. Development 124:3209-3219.

Taylor DS, Cheng X, Pawlowski JE, Wallace AR, Ferrer P, Molloy CJ (1999) Epiregulin is a potent vascular smooth muscle cell-derived mitogen induced by angiotensin II, endothelin-1, and thrombin. Proc Natl Acad Sci USA 96:1633-1638.

Toresson H, Potter SS, Campbell K (2000) Genetic control of dorsal-ventral identity in the telencephalon: opposing roles for Pax6 and Gsh2. Development 127:4361-4371.

Vaughan TJ, Pascall JC, Brown KD (1992) Nucleotide sequence and tissue distribution of mouse transforming growth factor-alpha. Biochim Biophys Acta 1132:322-324.

von Ohlen T, Doe CQ (2000) Convergence of dorsal, dpp, and egfr signaling pathways subdivides the Drosophila neuroectoderm into three dorsalventral columns. Dev Biol 224:362-372.

Wawersik S, Purcell P, Rauchman M, Dudley AT, Robertson EJ, Maas R (1999) BMP7 acts in murine lens placode development. Dev Biol 207:176-188

Wolpert L (1969) Positional information and the spatial pattern of cellular differentiation. J Theor Biol 25:1-47.

Xu PX, Woo I, Her H, Beier DR, Maas RL (1997) Mouse Eya homologues of the Drosophila eyes absent gene require Pax6 for expression in lens and nasal placode. Development 124:219-231.

Yun K, Potter S, Rubenstein JL (2001) Gsh2 and Pax6 play complementary roles in dorsoventral patterning of the mammalian telencephalon. Development 128:193-205.

Zhang D, Sliwkowski MX, Mark M, Frantz G, Akita R, Sun Y, Hillan K, Crowley C, Brush J, Godowski PJ (1997) Neuregulin-3 (NRG3): a novel neural tissue-enriched protein that binds and activates ErbB4. Proc Natl Acad Sci USA 94:9562-9567. 